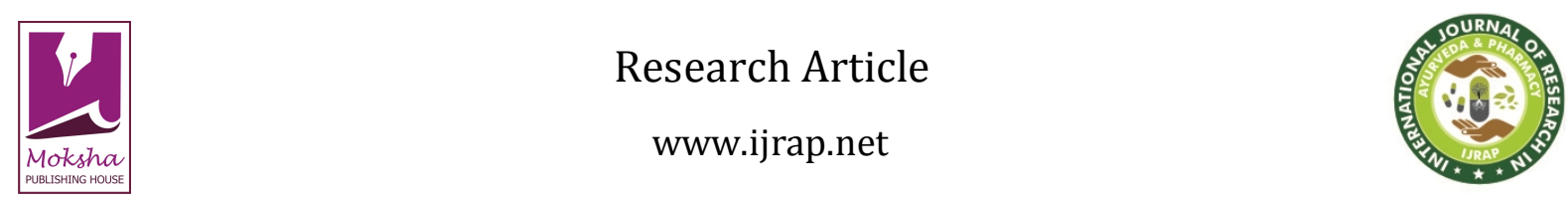

\title{
A CLINICAL STUDY OF PANCHAKOLA SIDDHA YAVAGU IN THE MANAGEMENT OF VATARAKTA SAMAVASTHA
}

Hemal R. Trivedi *1, Madhuri P. Bhide ${ }^{2}$, Janki B. Gajjar ${ }^{3}$

${ }^{1}$ P G Scholar (Final Year), Department of Samhita \& Siddhant, Bharati Vidyapeeth Deemed University, College of Ayurved, Pune, India

${ }^{2}$ Associate Professor, Department of Ayurved Samhita \& Siddhant, Bharati Vidyapeeth Deemed University, College of Ayurved, Pune, India

${ }^{3}$ P G Scholar (Final Year), Department of Agadtantra Avum Vidhi Vaidyaka, Bharati Vidyapeeth Deemed University College of Ayurved, Pune, India

Received on: 02/03/16 Revised on: 28/03/16 Accepted on: 09/04/16

\begin{abstract}
*Corresponding author
E-mail: trivedihemal@yahoo.com
\end{abstract}

DOI: $10.7897 / 2277-4343.07282$

\section{ABSTRACT}

Aushadha Siddha Yavagu Ahara Kalpana is one of the Ahara Kalpanas from which the purposes of nutritional value as well as medicated value are fulfilled. A randomized open clinical trial of Panchakola Siddha Yavagu on 30 patients of Vatarakta Samavastha has been screened on the patients were allocated to two groups. Group A having 15 cases received the trial drug as Avasthika Amapachana Chikitsa along with classical Vatarakta Chikitsa for 1 month and 15 cases in group B not received the trial drug but only classical Vatarakta Chikitsa for 35 days as the control group. Special scoring pattern was done for the assessment of Sandhu Shula; Agnimandya and Vatarakta Samavastha. The results obtained in trial group A have been very encouraging i.e. highly significant statistically. On the other side, there was a gradual improvement observed in the patients of control group B compare to the trial group patients. After the analysis of the results in both groups, patients of trial group A present remarkable improvement in Sandhi Shula, Agnimandya and Vatarakta Samavastha compare to control group B patients. The use of Panchakola Siddha Yavagu has served as an effective Avasthika Chikitsa for Vatarakta Samavastha. In all other Vyadhies, specific Aushadhi Siddha Yavagu mentioned in particular disease should be given as an Avasthika Chikitsa followed by Shamana Chikitsa of that specific disease for fast and better results.

Key words: Panchakola Siddha Yavagu, Vatarakta Samavastha.

\section{INTRODUCTION}

Ama (an intermediate toxin according To Ayurveda) is a causative factor of diseases; that would be necessary in many diseases to treat. For fast and the better results, it is essential to treat Samavastha first. Even Ama is the hidden cause of many Shakhashrita diseases, it can be inferred from the various symptoms present in the patients, though it is not stressfully, mentioned in all diseases. To rule out this hypothesis, the most commonly occurred disease which is most troublesome and pain-giving disease i.e. Vatarakta was selected for the clinical study. Vatarakta (Gout) is one of the main articular diseases, which is characterized by severe pain, tenderness, inflammation and burning sensation in the affected joints ${ }^{1}$. It is a Tridoshaja Vyadhi, with Vata Pradhanya; and Rakta as main Dushya. Compared with other Vatavyadhi, Vatarakta possesses a special place in the literature, due to its high prevalence in the society, increased incidence as age advances and so on $^{2}$. The incidence of Vatarakta varies in population from 0.2 to 3.5 per 1000, with an overall prevalence of 2.26 per 1000 .

In Vatarakta Samavastha Samprapti (pathogenesis), Vata gets blocked by Rakta (blood) and Ama; thus movement of Rakta also gets blocked i.e. Srotorodha. This leads to inflammation in extremities i.e. Sandhi Shotha. If the patient is treated by Dipana-Pachana Ushna Chikitsa (treatment) to get rid of Ama, that would be beneficial in reduction of Sandhi Shula and Shotha. Dipana-Pachana Chikitsa can be done in two ways, viz., one is by giving Dipana-Pachana Aushadhi Dravyas, and by giving these Aushadhi Siddha Ahara Kalpana (food recipes) like Peya, Vilepi, Yavagu. Amongst these Ahara Kalpanas, Yavagu (Gruel) itself has Dipana-Pachana quality and if processed with Dipana-Pachana Aushadhi Dravyas, it can become more beneficial and less harmful to the patients especially of Vatarakta Samavastha. To evaluate this principle practically, Pancakola Siddha Yavagu had been selected. This Panchakola Siddha Yavagu is stated in the second chapter i.e. ApamargaTanduliya Adhyaya of Bheshaja Chatushka of Charaka Samhita, known as Dipaniya and Shulaghni Yavagu ${ }^{3}$. Panchakola Siddha Yavagu is also stated in Shvayathu Chikitsitam Adhyaya of Charaka Samhita Chikitsa Sthana for the treatment of Shotha ${ }^{4}$. So this Yavagu would cure the Sandhi Shula by Shulaghni property, Sandhi Shotha by Shothaghna property and Samavastha by Dipaniya property.

\section{Need of study}

Ayurvedic Samhita do not directly mention in Vatarakta Vyadhi that its origin is Ama, but from its Hetu (etiological factors) like Adhyashan (intake the food before the previous food digested), Viruddhashana (unwholesome diets), Snigdhabhojana (excessive intake of sweet food), Divasvapa, and Ratrijagarana (to take sleep during day and remaining awake at night) etc. it can be inferred. Also from the symptoms like Alasya (laziness), Sandhi Gaurava (heaviness in affected joints), Anga Gaurava (heaviness of body) etc. its origin from Ama can be inferred. Clinically, in many cases, these Hetus and symptoms of Ama are seen. That Avastha (condition) of Vatarakta, where the 
history of symptoms of Ama is seen, can be called "Vatarakta Samavastha" (a condition of Gout similar to Rheumatoid Arthritis). Amongst Vatarakta patients, some patients are classically presented with Sama symptoms such as Sandhi Gaurava, Agnimandya (indigestion), Alasya, Anga Gaurava etc. These patients are also severely presented with Sandhi Shula and Shotha. Hence, the hypothesis was made to give step vise Avasthika Chikitsa in Vatarakta. Therefore, it was theorized that Sama Vatarakta should be given Dipana-Pachana Avasthika Chikitsa for the specific time. After curing the Samavastha the classical Chikitsa of Vatarakta i.e. Shita, Rakta-Pachaka and Tikta-Rasatmaka Chikitsa should be given. For this research work, two groups were made to compare and study the classical Chikitsa and the step vise Avasthika Chikitsa for Vatarakta Samavastha patients i.e. firstly the Ama-Pachana Chikitsa followed by the classical Chikitsa. The practically observed results would clarify the concept of Ama in Vatarakta.

\section{Previous research work}

Previously, Research on Panchakola Siddha Yavagu on Agnimandya by Sangita More ${ }^{9}$ has been done but no work has been done yet specifically on Panchakola Siddha Yavagu on Vatarakta Samavastha. So, this topic is selected for the research work.

\section{MATERIAL \& METHODS}

The study protocol was approved by the institutional ethics committee and ethical clearance for the trial was taken. Patients suffering from Vatarakta Samavastha having Sandhi Shula were selected from the OPD \& IPD of Bharati Vidyapeeth Medical Foundation's Ayurved Hospital and Research Centre, KatrajDhanakawadi, Pune-411043 and other Ayurvedic clinics in Pune. EC No: BVDU/COA/1323/2014-15 dated 06/05/2014.

\section{Inclusion Criteria}

1. The patients were diagnosed on the basis of clinical signs and symptoms of Vatarakta Samavastha having Sandhi Shula especially as studied in literary study.

2. Patients having above mentioned condition in the age group between $30-70$ years of either sex were selected.

\section{Exclusion Criteria}

1. The patient who are contraindicated for Yavagu Ahara Kalpana as per Ayurvedic classics were excluded for the study.

2. The patients having Vatarakta Niramavastha were excluded.

3. The patients suffering from chronic systemic diseases were excluded.

\section{Design of Groups}

For evaluate the effect of Panchakola Siddha Yavagu (Gruel) in Vatarakta Samavastha, the patients of the study were divided into two groups i.e. one was trial group and another is control group or observational group.

\section{Group A [trial group]}

In this group, patients were treated with Panchakola Siddha Yavagu for five days i.e. as Avasthika Amapachana Chikitsa.
Then for further one-month classical Shaman Chikitsa was given to those patients. Hence, total thirty-five days of treatment was given.

\section{Group B [control/observational group]}

In this group, Panchakola Siddha Yavagu was not given at all to the patients. Only classical Samana Chikitsa was started from the first day of the treatment and continued till thirty-five days.

\section{TRIAL DRUG- Panchakola Siddha Yavagu (Gruel)}

Preparation: As per Shrangdhar Acharya ${ }^{5}$, Panchakola Siddha Yavagu was prepared by Rakta Shali (red rice) boiled with 6 times of water in the stainless vessel till Shali was cooked properly. Pancakola Churna was added known as medicated Yavagu.

Dose and Dosage: Matra (dose) of the Rakta Shali was fixed i.e. 20 grams as per said by Acharya Chakrapani ${ }^{6}$, and 5 grams of Panchakola Churna was added. It was advised to the patients that Yavagu should be taken in every Annakala (the time when hunger arises like meal time, dinner time and breakfast time etc.) instead of any Ahara Dravya (food items). No other medication or food was advised to take during Yavagu Sevan Kala (Gruel administration time).

Authentication \& Standardizations: The authentication of the Panchakola Dravya i.e. Pippali (Piper longum), Pippali Mula (a root of Piper longum), Chavya (Piper retrofractum), Chitraka (Plumbago zeylanica) and Shunthi (Zingiber officinale) was done by using the botanical parameters from Department of Botany, University of Pune. Rakta Shali (for preparation of Yavagu) was purchased from the authentic source. The standardization of Panchakola Churna and Panchakola Siddha Yavagu was done from Late Prin. B. V. Bhide Foundation, For Education \& Research in Chemistry, Ayurveda \& Allied Sciences, Pune.

\section{Classical Shamana Chikitsa}

The classical Shamana Chikitsa was almost common in whole both groups. It was-

Aragvadha and Kampillak Churna were given for Mridu Virechana. Guduchi and Sariva Churna were given for Rakta Prasadana and Pitta Shamana. Mahasudarshan Churna was given with Anupana Shadanga Paniya as Tikta Pachaka. Pippali and Daruharidra Churna were given for Lina Dosha Pachana and Dipana.

\section{Criteria of Assessment}

The assessment was done by assessing 1) the cardinal symptom Sandhi Shula by S.D.S. (Simple Descriptive Scale) ${ }^{7}$ and V.A.S. (Visual Analogue Scale) ${ }^{8}$ pain scale methods; 2) Agni Parikshana; 3) Vatarakta Samavastha symptoms- a) Sandhi related symptoms and b) Sarvadaihika Amaj symptoms.

Overall percentage of improvement of each patient was calculated by the formulated ${ }^{9}$.

$$
\text { Total BT }- \text { Total AT } / \text { Total BT } \times 100=\%
$$




\section{RESULTS}

\section{Percentage of improvement in each criteria}

Table 1: SDS and VAS pain scale

\begin{tabular}{|c|c|c|c|c|c|c|}
\hline \multirow[t]{2}{*}{ Chief complaints } & \multicolumn{3}{|c|}{ Group A } & \multicolumn{3}{|c|}{ Group B } \\
\hline & $\begin{array}{c}\text { Number of } \\
\text { patients }\end{array}$ & $\begin{array}{c}\% \text { of imp. On } 5^{\text {th }} \\
\text { day }\end{array}$ & $\begin{array}{c}\% \text { of imp. On } \\
35^{\text {th }} \text { day }\end{array}$ & $\begin{array}{c}\text { Number of } \\
\text { patients }\end{array}$ & $\begin{array}{l}\% \text { of imp. On } \\
5^{\text {th }} \text { day }\end{array}$ & $\begin{array}{c}\% \text { of imp. On } \\
35^{\text {th }} \text { day }\end{array}$ \\
\hline SDS scale & 15 & $54.90 \%$ & $72.54 \%$ & 15 & $0 \%$ & $20.75 \%$ \\
\hline
\end{tabular}

Table 2: Abhyavaharana Shakti \& Jarana Shakti

\begin{tabular}{|c|c|c|c|c|c|c|}
\hline \multirow[t]{2}{*}{ Chief complaints } & \multicolumn{3}{|c|}{ Group A } & \multicolumn{3}{|c|}{ Group B } \\
\hline & $\begin{array}{c}\text { Number of } \\
\text { patients }\end{array}$ & $\begin{array}{c}\% \text { of imp. On } \\
5^{\text {th }} \text { day }\end{array}$ & $\begin{array}{c}\% \text { of imp. On } \\
35^{\text {th }} \text { day } \\
\end{array}$ & $\begin{array}{c}\text { Number } \\
\text { of patients }\end{array}$ & $\begin{array}{c}\% \text { of imp. On } \\
5^{\text {th }} \text { day }\end{array}$ & $\begin{array}{c}\text { \% of imp. On } \\
35^{\text {th }} \text { day } \\
\end{array}$ \\
\hline Abhyavaharana Shakti & 15 & $63.88 \%$ & $86.11 \%$ & 15 & $0 \%$ & $21.05 \%$ \\
\hline Deha Laghava & 15 & $100 \%$ & $100 \%$ & 15 & $0 \%$ & $30 \%$ \\
\hline Kshudha & 15 & $95.23 \%$ & $100 \%$ & 15 & $0 \%$ & $23.80 \%$ \\
\hline Utsaha & 15 & $95 \%$ & $100 \%$ & 15 & $3.84 \%$ & $46.15 \%$ \\
\hline
\end{tabular}

Table 3: Sandhi related symptoms

\begin{tabular}{|c|c|c|c|c|c|c|}
\hline \multirow[t]{2}{*}{ Chief complaints } & \multicolumn{3}{|c|}{ Group A } & \multicolumn{3}{|c|}{ Group B } \\
\hline & $\begin{array}{c}\text { Number of } \\
\text { patients }\end{array}$ & $\begin{array}{l}\% \text { of imp. On } 5^{\text {th }} \\
\text { day }\end{array}$ & $\begin{array}{c}\text { \% of imp. On } \\
35^{\text {th }} \text { day }\end{array}$ & $\begin{array}{c}\text { Number of } \\
\text { patients }\end{array}$ & $\begin{array}{l}\text { \% of imp. } \\
\text { On } 5^{\text {th }} \text { day }\end{array}$ & $\begin{array}{c}\% \text { of imp. On } 35^{\text {th }} \\
\text { day }\end{array}$ \\
\hline Sandhi Shotha & 15 & $63.41 \%$ & $90.24 \%$ & 15 & $0 \%$ & $28.57 \%$ \\
\hline Sandhi Supti & 15 & $61.53 \%$ & $96.15 \%$ & 15 & $0 \%$ & $17.64 \%$ \\
\hline Anga Graha & 15 & $54.54 \%$ & $75.75 \%$ & 15 & $0 \%$ & $11.11 \%$ \\
\hline Sandhi Shula & 15 & $57.14 \%$ & $75.51 \%$ & 15 & $0 \%$ & $21.56 \%$ \\
\hline Shita Pradvesha & 15 & $80 \%$ & $100 \%$ & 15 & $0 \%$ & $11.11 \%$ \\
\hline Staimitya & 15 & --- & --- & 15 & --- & --- \\
\hline
\end{tabular}

Table 4: Sarvadaihika Amaj symptoms

\begin{tabular}{|c|c|c|c|c|c|c|}
\hline \multirow[t]{2}{*}{ Chief complaints } & \multicolumn{3}{|c|}{ Group A } & \multicolumn{3}{|c|}{ Group B } \\
\hline & $\begin{array}{c}\text { Number of } \\
\text { patients }\end{array}$ & $\begin{array}{c}\text { \% of imp. On } \\
5^{\text {th }} \text { day } \\
\end{array}$ & $\begin{array}{c}\% \text { of imp. On } \\
35^{\text {th }} \text { day } \\
\end{array}$ & $\begin{array}{c}\text { Number of } \\
\text { patients }\end{array}$ & $\begin{array}{l}\% \text { of imp. } \\
\text { On } 5^{\text {th }} \text { day }\end{array}$ & $\begin{array}{c}\% \text { of imp. On } 35^{\text {th }} \\
\text { day }\end{array}$ \\
\hline Gaurava & 15 & $90 \%$ & $96.66 \%$ & 15 & $0 \%$ & $14.70 \%$ \\
\hline Apakti & 15 & $95.55 \%$ & $100 \%$ & 15 & $3.77 \%$ & $24.52 \%$ \\
\hline Aruchi & 15 & $93.47 \%$ & $100 \%$ & 15 & $3.77 \%$ & $24.52 \%$ \\
\hline Alasya & 15 & $85.18 \%$ & $96.29 \%$ & 15 & $0 \%$ & $17.85 \%$ \\
\hline Anilamudhata & 15 & $92.85 \%$ & $100 \%$ & 15 & $0 \%$ & $38.88 \%$ \\
\hline Klama & 15 & $59.09 \%$ & $86.36 \%$ & 15 & $0 \%$ & $13.63 \%$ \\
\hline Malasanga & 15 & $100 \%$ & $100 \%$ & 15 & $5.40 \%$ & $45.94 \%$ \\
\hline Balabhransha & 15 & $52.77 \%$ & $80.55 \%$ & 15 & $0 \%$ & $14.70 \%$ \\
\hline Nishthiva & 15 & $100 \%$ & $100 \%$ & 15 & $0 \%$ & $16.66 \%$ \\
\hline Sama-Mala Pravritti & 15 & $96.29 \%$ & $100 \%$ & 15 & $0 \%$ & $40.74 \%$ \\
\hline
\end{tabular}

\section{DISCUSSION}

After the clinical study it can be stated that, on the 5th day after the Panchakola Siddha Yavagu treatment, the miraculous significant results were shown in the patients of Group A than the patients of Group B. Similarly, the Group A patients got marked improvement on the 35th day after the classical Vatarakta Chikitsa. Group B does not have marked improvement. The Amaj symptoms of patients such as Gaurava, Aruchi, Alasya etc. were replaced by the symptoms Laghava, Annaruchi and Utsaha etc. This denotes that reduction of the Sandhi Shula and Shotha was not outcome of symptomatic treatment but was the result due to removal of Ama-Dosha.

\section{CONCLUSION}

The use of Panchakola Siddha Yavagu has served as an effective Avasthika Chikitsa for the Vatarakta Samavastha. In all other Vyadhies, specific Aushadhi Siddha Yavagu mentioned in that particular disease should be given as Avasthika Chikitsa followed with Shamana Chikitsa of that specific disease for fast and better results.

\section{REFERENCES}

1. Agnivesha, Charak Samhita with Ayurveda Dipika commentary by Chakrapani, Vaidya Yadavji Trikamji Acharya, Chaukamba orientalia, Varanasi, $5^{\text {th }}$ edition 
2. Shivaprasad Huded, Sonia V Gummadi, Kuber Sankh, Asha H.N., Ashwini H.S., Lingadore K. Evaluation of Guduchi Yoga in the management of Vatarakta (gouty arthritis): A clinical study. Int. J. Res. Ayurveda Pharm. 2013;4(5):688692 http://dx.doi.org/10.7897/2277-4343.04512

3. Agnivesha, Charak Samhita with Ayurveda Dipika commentary by Chakrapani, Vaidya Jadavji Trikamji Acharya, Sutra Sthana, Adhyaya 2, Shloka 18, Chaukamba orientalia, Ed.2013.

4. Agnivesha, Charak Samhita with Ayurveda Dipika commentary by Chakrapani, Vaidya Jadavji Trikamji Acharya, Chikitsa Sthana, Adhyaya 12, Shloka 161, Chaukamba orientalia, Ed.2013.

5. Brahmanand Tripathi, Sarangadhara Samhita with Dipika Hindi commentary, Madhyakhanda, Adhyaya 2, Shloka 152, Chaukamba orientalia, Ed. 2011, P.156

6. Agnivesha, Charak Samhita with Ayurveda Dipika commentary by Chakrapani, Vaidya Jadavji Trikamji Acharya, Sutra Sthana, Adhyaya 2, Shloka 17, Chaukamba orientalia, Ed.2013
7. W.W.Downie et al, Studies with pain rating scales, Annals of the Rhuematic diseases, 1978, P.378-381

8. Gillian A. Hawker et al, Measures of adult pain: Visual Analouge Scale for pain (VAS pain), Nemeric Rating Scale for pain (NRS pain), McGill pain Questionnaire (MPQ), Short-Form McGill pain Questionnaire (SF-MPQ),Chronic pain Grade scale (CPGS), Short-Form-36 Bodily pain scale (SF-36 BPS) and Measure of International and constant Osteoarthritis pain (ICOAP); Arthritis care \& research; Vol 63, Issue Supplement S11, Pgs S240-S252, November 2011

9. Sangita More R R Dwivedi, A clinical Study of Panchakola Siddha Yavagu in the management of Agnimandya, AYU, Jen-Mar 2011, Vol 32, Issue 1, P.70-75, IP:75,101.163.131

\section{Cite this article as:}

Hemal R. Trivedi, Madhuri P. Bhide, Janki B. Gajjar. A clinical study of panchakola siddha yavagu in the management of vatarakta samavastha. Int. J. Res. Ayurveda Pharm. Mar - Apr 2016;7(Suppl 2):181-184 http://dx.doi.org/10.7897/22774343.07282

Disclaimer: IJRAP is solely owned by Moksha Publishing House - A non-profit publishing house, dedicated to publish quality research, while every effort has been taken to verify the accuracy of the content published in our Journal. IJRAP cannot accept any responsibility or liability for the site content and articles published. The views expressed in articles by our contributing authors are not necessarily those of IJRAP editor or editorial board members. 